\title{
The Role of Twitter During the COVID-19 Crisis: A Systematic Literature Review
}

\author{
Mahsa Dalili Shoaei ${ }^{1}$ (D), Meisam Dastani ${ }^{2}$ (D)
}

\begin{abstract}
At the end of 2019, COVID-19 (Coronavirus 2019) emerged in Wuhan, China, and spread rapidly worldwide. The use of virtual social networks, especially Twitter, has increased due to the present condition. The purpose of the present systematic literature review is to review the investigations on Twitter's role in the COVID-19 crisis. For this purpose, an appropriate search strategy was used to extract the studies conducted in the Web of Science and PubMed databases. In the end, 24 articles were reviewed. The results indicate that in the period of the COVID-19 pandemic, the content and tweets posted on Twitter were affected by this crisis, and various people such as the general public, health professionals, and politicians were sharing opinions, emotions, personal experience, and educational content about exposure to COVID-19 on this social media. Therefore, the speed of providing information to people has been one of the main advantages of Twitter during the crisis of COVID-19; however, the risk of using invalid information without scientific citation is also one of the most important concerns of using Twitter among people as well as health and governmental organizations. Thus, users should evaluate information accuracy more carefully and pay attention to the quality and validity of information before employing or sharing it. Governments and professionals can also prevent this disease's contagion even in similar future crises by employing Twitter correctly in the period of crisis and using the useful experience gained from applying social networks in the outbreak of COVID-19.
\end{abstract}

Keywords: COVID-19, Crisis, Pandemic, Review, Role, Social media, Twitter.

\section{Introduction}

COVID-19 viral disease (Coronavirus 2019) emerged in December 2019 in Wuhan, China, and it quickly spread worldwide ( $\mathrm{Li}$ et al., 2020); it is a severe problem for public health. Considering that no specific controls or methods have yet been developed to prevent and treat this disease, people's self-care and self-control is extremely important to prevent the spread of this disease. One way to control and prevent this disease's spread is staying at home, avoiding daily physical interactions, and living in home quarantine (Hou et al., 2020).

This epidemic has affected many people's lives in different nations. With vast numbers of people pushed out of public places, there are already many social media discussions on these phenomena (Chen et al., 2020a). The discussion of COVID-19 has continued to extend as social

\footnotetext{
${ }^{1}$ Ferdows School of Paramedical and Health, Birjand University of Medical Sciences, Birjand, Iran

${ }^{2}$ Gonabad University of Medical Sciences, Gonabad, Iran

$\bowtie$ meisam.dastani@gmail.com
} 
interactions in online space grow, with increasing numbers shifting to social media for both company and information (Abbas et al., 2020).

Social media or social networks are web-based tools applied for communication through computer systems, making it possible to build two-way communication between users. Because of the development of the first type of social media, various types of these network tools have been developed and for many people employing these networks is considered a daily routine (Boyd \& Ellison, 2007; Dastani et al., 2016; Dastani et al., 2019). Instagram, Telegram, Facebook, Twitter, and WhatsApp are among the most important websites and popular social networking applications (Amani et al., 2020; Dastani et al., 2019).

These virtual networks are more useful and effective in forming new relationships (Madgeet al., 2009; Walther \& Parks, 2002), maintaining current and past relationships (Dastani et al., 2015), facilitating communication (Pempek, Yermolayeva, \& Calvert, 2009), improving social participation (Dastani et al., 2019), and increasing knowledge and job skills (Dastani \& Ramezani, 2017). On the other hand, spreading rumors and invalid information and the lack of monitoring of these networks (Dastani et al., 2019) are among social media threats.

Many experiments have found that individuals effectively utilize online information in different crises, such as a public health emergency (Gui et al., 2017; Rizo et al., 2005). The emotional and informational exchanges among internet users cause the development of people's concerns and opinions that affect people's awareness and behaviors. Nevertheless, these thoughts and knowledge are often valuable but not particularly applicable information on the Internet. False information may be shared, leading to improper medical recommendations or increased anxiety (Auter et al., 2016; Barros et al., 2020; Wang et al., 2019).

During the COVID-19 pandemic, huge numbers of people used social media to exchange and gain information regarding COVID-19. However, the characteristics of extreme ineffectiveness, irrationality, and conformity are attributed to public views on social media. With the expansion of web-based networking and social technologies, wide public involvement in emergency response has been increased by the widespread usage of social media (Goodchild \& Glennon, 2010; Liu et al., 2014).

An increasing number of people utilize location-based social network services (e.g. Twitter or Facebook) to build time-stamped geo-located data and communicate information regarding the details of their surroundings (Chae et al., 2014). Platforms such as Twitter are vital to the social and technological system that allows people to be connected even throughout the emergencies (Chen et al., 2020b).

Twitter (created in July 2006) is a microblogging type of social media site on which users interact in real-time through posts ("tweets") comprising up to 280 characters; hashtags (\#) within posts allow aggregation of tweets into subjects. Users communicate with each other by direct messaging, updates, replies, retweeting, and likes (retweeting is the reposting of particular messages). No permission is required to follow a user, and the reciprocation of following is not necessary. Twitter has announced 330 million active monthly users in its firstquarter statistics for 2019 (Kullar et al., 2020). As a social media platform, Twitter facilitates user-generated thoughts, feelings, and health condition real-time research with concomitant demographic information (Panuganti et al., 2020). Top tweets included 'likes', 'retweets', and 'comments. A 'like' indicates that a tweet is appreciated by a registered Twitter user, while a 'retweet' indicates that they have shared the tweet on their own Twitter page and a 'comment' indicates that they have added written commentary for the tweet. All of these actions increase the reach of the viral tweet in question (Rufai \& Bunce, 2020). With 152 million daily users, Twitter has become an everyday part of the lives of many healthcare experts and helps them to 
convey medical information and warnings in real time to a broad global audience, especially those who are regarded as specialists and thought leaders of a specific area, and to receive opinions (Kullar et al., 2020).

Twitter is one of the most popular social media in times of crisis and disaster due to its information resharing capabilities (Vieweg, 2010). Twitter is a tool for sharing information and is also considered a form of social media that contributes significantly to the interactions between its users.

Previous investigations indicate that in past crises, especially in the outbreak of infectious diseases, Twitter has played an important role in users' interactions and has been particularly effective in the public health system, e.g. in controlling the swine flu epidemic in 2009 (Kostkova et al., 2010), and identifying the Ebola conflict zones in South Africa in 2014 using users' tweets (Odlum and Yoon, 2015). Twitter has also been essential for engaging, educating, and supporting people in the global health crisis of antimicrobial resistance (AMR) (Goff et al., 2019).

However, some studies have also indicated that the spread of rumors and false news is faster, deeper, and broader than that of true news (Vosoughi et al., 2018). In fact, the increase in misinformation leads to the denial of scientific evidence and can potentially pose a threat to societies (Allcott et al., 2019). One of the most important examples of the negative effect of false news is in the field of health. In this context, investigations revealed that misinformation can have severe consequences for public health (Scheufele and Krause, 2019).

Due to the addressed issues and the importance of using social networks, especially Twitter, in the exchange of information and opinions among users, the purpose of the present review is to evaluate the role of social networks in the period of the COVID-19 crisis and its consequences. Thus, the research objectives of the present study are responding to the following questions:

- Who published tweets related to COVID-19?

- What were the tweets about COVID-19 related to?

- What were the advantages and disadvantages of using Twitter during the COVID-19 crisis?

\section{Methodology}

The present study is a systematic literature review (Paré \& Kitsiou, 2017) and performed in accordance with the principles of PRISMA (2015). designed to collect published research and papers on comments on COVID-19 by Twitter users. In this study, all publications published in two databases, PubMed and Web of Science, have been searched and reviewed using MeSHcompliant keywords, including Tweet, Twitter, and COVID-19 (Table 1).

\begin{tabular}{|c|c|}
\hline Database & Search Strategies \\
\hline PubMed & $\begin{array}{c}\text { ((((()(((2019-nCoV infection) OR } 2019 \text { novel coronavirus disease) OR 2019-nCoV disease) } \\
\text { OR } 2019 \text { novel coronavirus infection) OR coronavirus disease-19) OR coronavirus disease } \\
\text { 2019) OR COVID19) OR COVID-19)) AND (((tweet) OR twitter)) }\end{array}$ \\
\hline $\begin{array}{l}\text { Web of } \\
\text { Science }\end{array}$ & $\begin{array}{l}\text { (COVID-19 OR COVID19 OR (coronavirus disease 2019) OR (coronavirus disease-19) OR } \\
\text { (2019 novel coronavirus infection) OR (2019-nCoV disease) OR (2019 novel coronavirus } \\
\text { disease) OR (2019-nCoV infection))) AND ((tweet) OR (twitter)) }\end{array}$ \\
\hline
\end{tabular}

Table 1. Search strategies. 
One hundred two (102) records were generated form database searches on July 7, 2020. After removing duplicates, 94 abstracts remained. At the final evaluation of full-text articles, 24 were retained for data extraction; see the flow diagram in Figure 1.

Identification

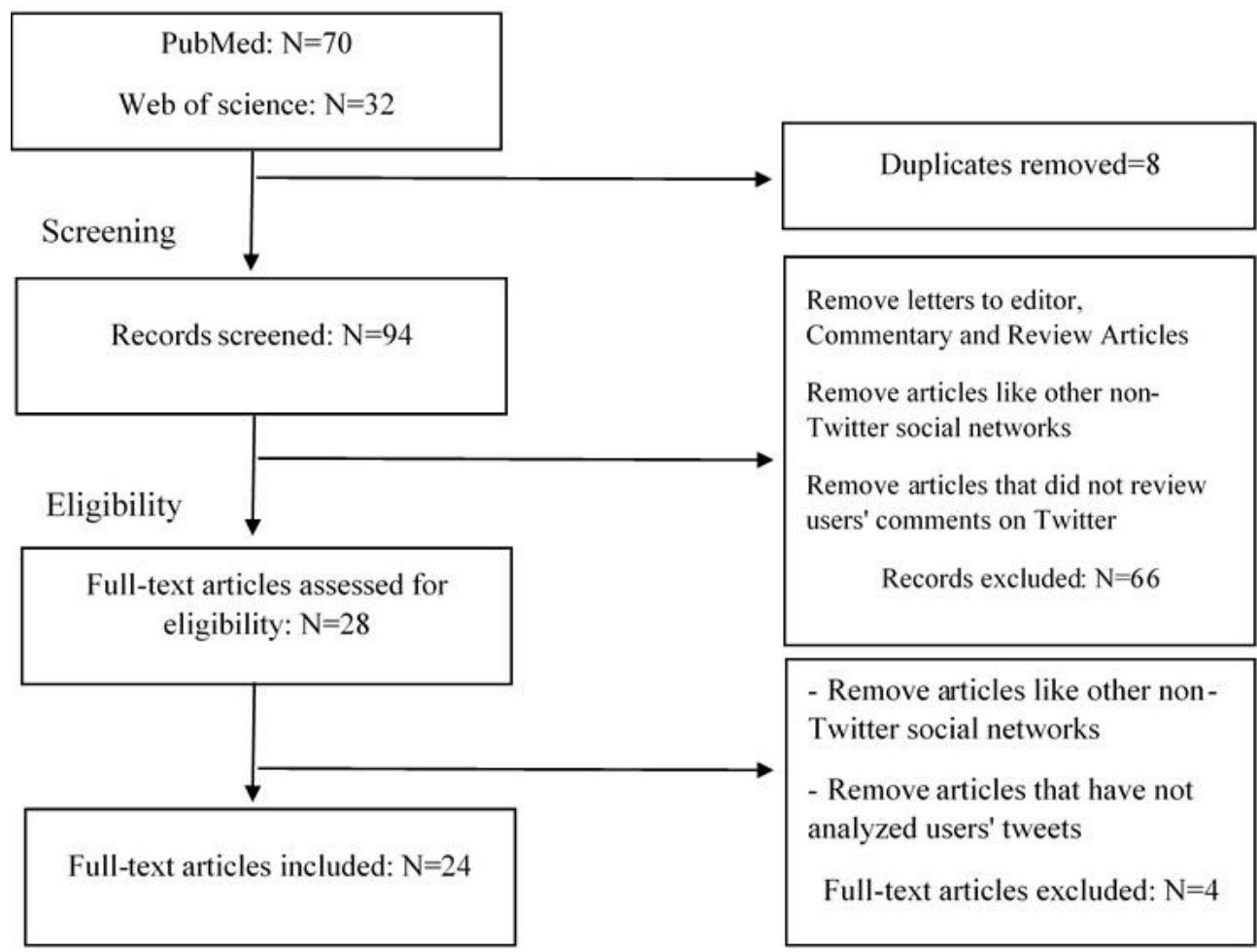

Figure 1. Flow diagram: Search outputs, study identification, and inclusion. Source: Authors.

The titles and abstracts of all published papers were evaluated independently by applying specific keywords, and the corresponding papers were collected and summarized, and a report of the findings was written by two researchers.

\section{Results}

Because the outbreak of the COVID-19 disease caused a significant crisis, the information published about this crisis on social media, especially Twitter, has increased with an unprecedented trend, which is also referred to as an unprecedented increase in information and information tsunami (Kouzy et al., 2020). In this regard, Banda et al. 2020 showed in their studied dataset that COVID-19-related tweets reached 6,737,875 in January and 110,220,360 in March.

Golder et al. (2020) also showed that the total volume of people's conversations related to the experiences and suspicious symptoms they have experienced during COVID-19 disease, the lack of access to testing and discussion about the recovery of people suspected or definitely exposed to the disease sharply increased during the research period (March 3 to 20), as presented in Figure 2. 

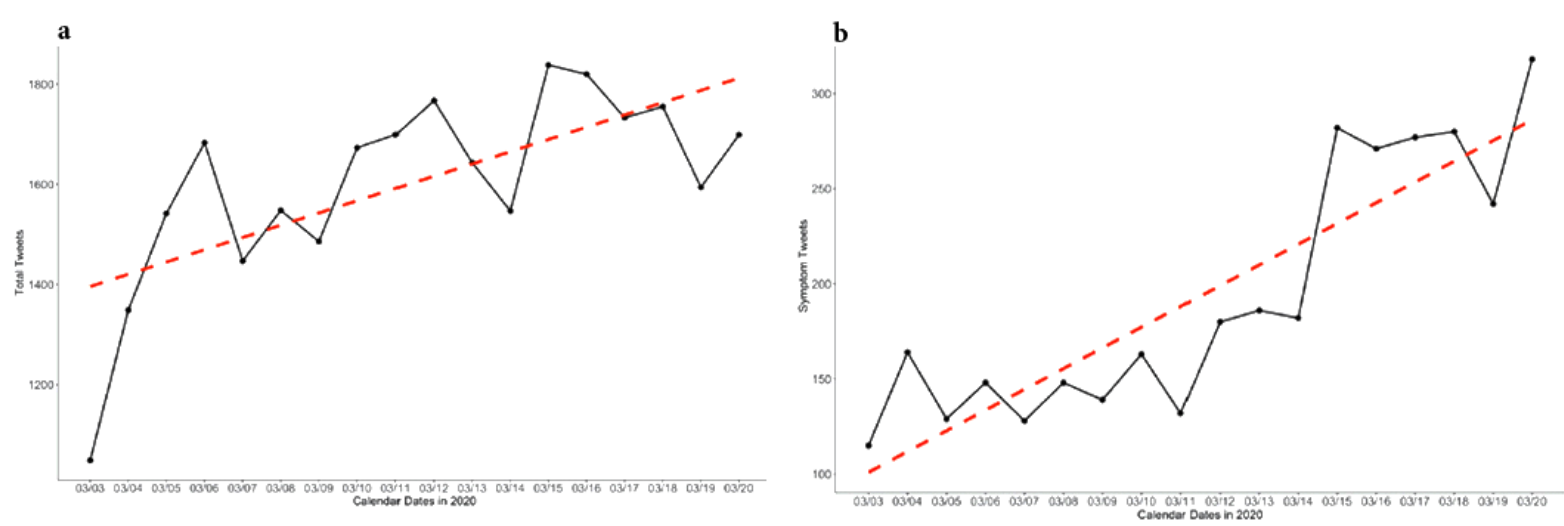

Figure 2. The volume of a) confirmed symptom tweets and b) the coronavirus disease symptom tweets. Source: (Golder et al., 2020).

Many people use social media, such as Twitter, to inform, exchange, send, and search for information (Aguilar-Gallegos et al., 2020). The users on this social media are also interested in informing and warning their friends and followers about COVID-19 (Abd-Alrazaq et al., 2020). The spread of COVID-19 in any geographical area has led to the growth of the number of tweets and hashtags related to this disease (Bisanzio et al., 2020; Chen et al., 2020; Golder et al., 2020; Klein et al., 2020) and also an increase in the search for information about the symptoms of this disease (Panuganti et al., 2020). An analysis of tweets shared by users in the United States indicated that people seek information about government measures on Corona, the number of people infected in the country and the world, and prevention and treatment methods against COVID-19 (Yum, 2020).

Depending on the type of information shared and the role of information sources (politicians, health care providers, and regular users), twitter users use different hashtags along with tweets and information on COVID-19, including hashtags used in related tweets on COVID-19 and other hashtags such as Coronavirus, Pandemic, Corona, COVID-19, Wuhan (Aguilar-Gallegos et al., 2020; Chen et al., 2020b).

Aguilar-Gallegos et al. (2020) by employing a word cloud showed the diversity of multilingual hashtags used about the coronavirus topic from January 21 to February 12, 2020, i.e. 23 days (Figure 3).

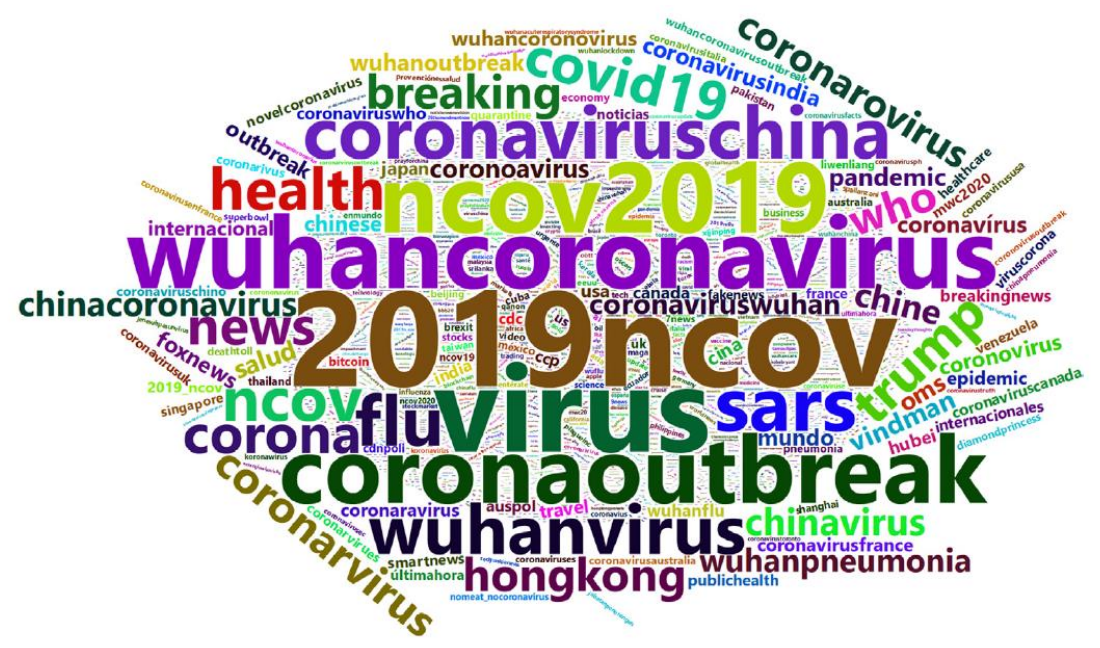

Figure 3. The word cloud of hashtags used in tweets about the coronavirus topic. Source: (Aguilar-Gallegos et al., 2020). 
Leelawat et al. (2020) also indicated that before the official announcement of the name COVID19 by the World Health Organization (WHO), many terms such as SARS, nCOV, and Coronavirus were being employed by Twitter users due to the lack of an official name and the similarity of the disease to past diseases. After February 11, 2020, with the official announcement of the name COVID-19, this name started to be used extensively among Twitter users (see Figure 4).

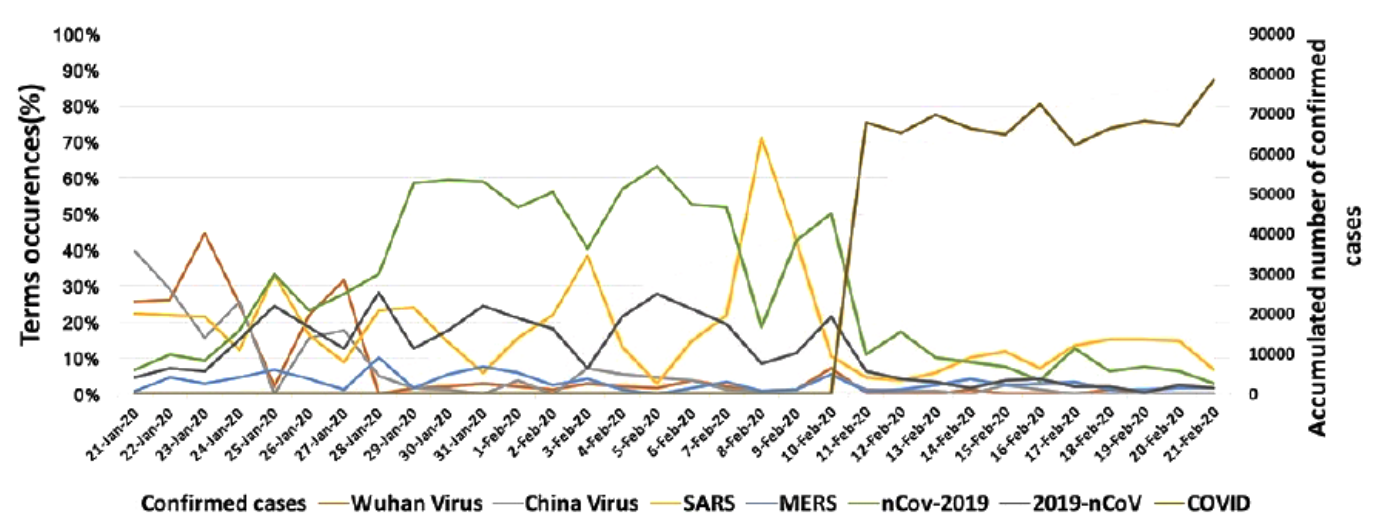

Figure 4. The trends of COVID-19-related tweets in English. Source: (Leelawat et al., 2020).

\subsection{Topics Discussed in the Tweets}

Users' comments on Twitter are posted by three types of users: regular users, healthcare professionals, and political leaders. Several studies have presented different findings on users' comments (tweets), the descriptions of which are listed in Table 2.

\begin{tabular}{|c|c|c|}
\hline Row & Title & Topics \\
\hline 1 & $\begin{array}{l}\text { Extending a Chronological and } \\
\text { Geographical Analysis of Personal } \\
\text { Reports of COVID-19 on Twitter to } \\
\text { England, UK (Golder et al., 2020) }\end{array}$ & $\begin{array}{l}\text { - Tweets about testing for COVID-19 and the result of the corona } \\
\text { test } \\
\text { - Exposure to COVID-19 disease and its symptoms }\end{array}$ \\
\hline 2 & $\begin{array}{l}\text { A Chronological and Geographical } \\
\text { Analysis of Personal Reports of } \\
\text { COVID-19 on Twitter (Klein et al., } \\
\text { 2020) }\end{array}$ & $\begin{array}{l}\text { - Tweets about testing for COVID- } 19 \text { and the result of the corona } \\
\text { test and observing health protocols such as social distancing, } \\
\text { avoiding unnecessary travel, and other items related to the } \\
\text { COVID-19 disease } \\
\text { - Exposure to the COVID-19 disease and its symptoms }\end{array}$ \\
\hline 3 & $\begin{array}{l}\text { Machine Learning to Detect Self- } \\
\text { Reporting of Symptoms, Testing } \\
\text { Access, and Recovery Associated } \\
\text { with COVID-19 on Twitter: } \\
\text { Retrospective } \quad \text { Big } \\
\text { Infoveillance Study (Mackey et al., } \\
2020 \text { ) }\end{array}$ & $\begin{array}{l}\text { - People's tweets about their experience with symptoms that may } \\
\text { be related to the COVID-19 disease, but due to lack of testing } \\
\text { they are not sure if these symptoms are related to this disease or } \\
\text { not, as well as people's experience with the course of treatment } \\
\text { of COVID-19 }\end{array}$ \\
\hline 4 & $\begin{array}{l}\text { Self-reported COVID-19 symptoms } \\
\text { on Twitter: an analysis and a } \\
\text { research resource (Sarker et al., } \\
\text { 2020) }\end{array}$ & $\begin{array}{l}\text { - Users have expressed their symptoms and described the } \\
\text { progress of the disease by tweeting on Twitter }\end{array}$ \\
\hline 5 & $\begin{array}{l}\text { Coronavirus, Ageism, and Twitter: } \\
\text { An Evaluation of Tweets about }\end{array}$ & $\begin{array}{l}\text { - Tweets retrieved from social media categorized into six groups: } \\
\text { 1. Instructive, 2. Personal experiences, 3. Personal comments, } 4 . \\
\text { Consultation, 5. Jokes, 6. Miscellaneous }\end{array}$ \\
\hline
\end{tabular}




\begin{tabular}{|c|c|c|}
\hline Row & Title & Topics \\
\hline & $\begin{array}{l}\text { Older Adults and COVID-19 } \\
\text { (Jimenez-Sotomayor et al. 2020) }\end{array}$ & $\begin{array}{l}\text { - Also, tweets about people with certain conditions (regarding } \\
\text { the outbreak of COVID-19 in middle-aged people with a } \\
\text { ridiculous and insulting language) }\end{array}$ \\
\hline 6 & $\begin{array}{l}\text { World leaders' usage of Twitter in } \\
\text { response to the COVID-19 } \\
\text { pandemic: a content analysis (Rufai } \\
\text { \& Bunce, 2020) }\end{array}$ & $\begin{array}{l}\text { - Classification of politicians' tweets (for communicating with } \\
\text { citizens and sharing information from official government } \\
\text { sources) into informative, morale-boosting, and political } \\
\text { categories }\end{array}$ \\
\hline 7 & $\begin{array}{l}\text { Mining Physicians' Opinions on } \\
\text { Social Media to Obtain Insights Into } \\
\text { COVID-19: Mixed Methods } \\
\text { Analysis (Wahbeh et al., 2020) }\end{array}$ & $\begin{array}{l}\text { - Classification of physicians' and health professionals' tweets } \\
\text { regarding the topics of measures and recommendations, coping } \\
\text { with false information and the capacity of the health care system } \\
\text { to handle the COVID-19 epidemic, information, and knowledge, } \\
\text { symptoms and disease, immunity, and safety of people against } \\
\text { the coronavirus, tests related to COVID-19, infection, and } \\
\text { transmission }\end{array}$ \\
\hline 8 & $\begin{array}{l}\text { Top Concerns of Tweeters During } \\
\text { the COVID-19 Pandemic: } \\
\text { Infoveillance Study. Journal of } \\
\text { Medical Internet Research (Abd- } \\
\text { Alrazaq et al., 2020) }\end{array}$ & $\begin{array}{l}\text { - Classification in terms of } 1 \text {. The impact of COVID-19 on } \\
\text { people and countries, } 2 \text {. The number of deaths caused by the } \\
\text { COVID-19 disease, } 3 \text {. The emotional and psychological impact } \\
\text { of the disease on individuals, } 4 \text {. Fear and concern of people about } \\
\text { the lack of vaccination and specific drugs against COVID-19, } 5 \text {. } \\
\text { Economic effects of COVID-19, 6. Traveling during the } \\
\text { outbreak of this disease, 7. Potential sources of COVID-19: } \\
\text { eating meat, the Military Biological Laboratory of China, etc., } 8 \text {. } \\
\text { Main methods to reduce the spread of COVID-19 }\end{array}$ \\
\hline 9 & $\begin{array}{l}\text { Retweeting COVID-19 disability } \\
\text { issues: Risks, support, and outrage } \\
\text { (Thelwall \& Levitt, 2020) }\end{array}$ & $\begin{array}{l}\text { Tweets related to people with certain conditions are categorized } \\
\text { as follows: } \\
\text { - Support for people with disabilities against this disease } \\
\text { - Lack of attention to people with physical disabilities } \\
\text { - Most people with disabilities are at risk } \\
\text { - Reports on the death of people with disabilities due to COVID- } \\
19 \text { as a warning } \\
\text { - Principles of care for people with disabilities } \\
\text { - The skills of people with disabilities to use communication } \\
\text { technologies } \\
\text { - Other problems related to people with disabilities and COVID- } \\
19\end{array}$ \\
\hline
\end{tabular}

Table 2. The topics discussed in the content of tweets published about COVID-19.

\subsection{Analysis of Emotions Behind Users' Shared Tweets}

The analysis of emotions behind users' shared tweets at different times reveals various experiences causing emotions such as fear, anger, sadness, and happiness (Leelawat et al., 2020; Lwin et al., 2020). For instance, with the increase in the prevalence of this disease, the fear of the lack of tests and medical equipment appeared. Tweets showing people's sadness were due to the loss of friends and acquaintances, and tweets with happiness behind them came from hope, appreciation, and resistance. Tweets with anger themes were due to social isolation and staying at home. Fear and anger were the first emotions that appeared after the outbreak of COVID-19; after the official announcement of the disease, the number of tweets with fear and anger themes decreased, and sadness increased in tweets (Lwin et al., 2020).

Moreover, the analysis of users' shared tweets revealed the different emotional and psychological condition of users before and after home quarantine, so that the words shared on 
social media changed significantly before and after quarantine; people's stress level reduced and their leisure time increased during quarantine (Su et al., 2020).

\subsection{Advantages and Disadvantages of Using Twitter During COVID-19 Outbreak}

The use of Twitter during the COVID-19 pandemic had some advantages and disadvantages, discussed in Table 3.

\begin{tabular}{|c|c|c|c|}
\hline \multirow{2}{*}{ Row } & \multirow{2}{*}{ Title } & \multicolumn{2}{|c|}{ Consequence } \\
\hline & & Advantage & Disadvantage \\
\hline 1 & $\begin{array}{l}\text { Top Concerns of Tweeters During } \\
\text { the COVID- } 19 \text { Pandemic: } \\
\text { Infoveillance Study (Abd-Alrazaq et } \\
\text { al., 2020) }\end{array}$ & $\begin{array}{l}\text { - The use of twitter as an active } \\
\text { media in communicating about } \\
\text { COVID-19 between individuals, } \\
\text { organizations, and governments }\end{array}$ & $\begin{array}{l}\text { - Emotional use of Twitter } \\
\text { causes rapid spread of false } \\
\text { opinions and information } \\
\text { among individuals in the } \\
\text { context of the digital world }\end{array}$ \\
\hline 2 & $\begin{array}{l}\text { Dataset on Dynamics of Coronavirus } \\
\text { on Twitter (Aguilar-Gallegos et al., } \\
\text { 2020) }\end{array}$ & $\begin{array}{l}\text { - The use of twitter to provide } \\
\text { proper viewpoints on the } \\
\text { outbreak of the disease }\end{array}$ & - \\
\hline 3 & $\begin{array}{l}\text { A large-scale COVID-19 Twitter } \\
\text { chatter dataset for open scientific } \\
\text { research an international } \\
\text { collaboration (Banda et al., 2020) }\end{array}$ & $\begin{array}{l}\text { - The use of available data on } \\
\text { Twitter for research purposes }\end{array}$ & - \\
\hline 4 & $\begin{array}{l}\text { Use of Twitter Social Media activity } \\
\text { as a proxy For human mobility to } \\
\text { predict the spatiotemporal spread of } \\
\text { COVID-19 at the global scale } \\
\text { (Bisanzio et al., 2020) }\end{array}$ & $\begin{array}{l}\text { - The use of available data on } \\
\text { Twitter to identify geographical } \\
\text { areas at risk of the COVID-19 } \\
\text { disease } \\
\text { - The use of available data on } \\
\text { Twitter to create a global and } \\
\text { local warning system to } \\
\text { improve public health and } \\
\text { treatment measures at the } \\
\text { international and national levels }\end{array}$ & - \\
\hline 5 & $\begin{array}{l}\text { Creating COVID-19 Stigma by } \\
\text { Referencing the Novel Coronavirus } \\
\text { as the "Chinese virus" on Twitter: } \\
\text { Quantitative Analysis of Social } \\
\text { Media Data (Budhwani \& Sun, } \\
\text { 2020) }\end{array}$ & - & $\begin{array}{l}\text { - In some tweets, } \\
\text { developing fear and } \\
\text { distrust of the public health } \\
\text { and treatment system in } \\
\text { each country }\end{array}$ \\
\hline 6 & $\begin{array}{l}\text { Tracking Social Media Discourse } \\
\text { About the COVID-19 Pandemic: } \\
\text { Development of a Public } \\
\text { Coronavirus Twitter Data Set (Chen } \\
\text { et al., 2020b) }\end{array}$ & $\begin{array}{l}\text { - The use of Twitter to inform of } \\
\text { important events such as the } \\
\text { news on the outbreak of } \\
\text { COVID-19 by influential people } \\
\text { and news sources in a country } \\
\text { - Identifying false information } \\
\text { about COVID-19 and published } \\
\text { rumors } \\
\text { - Identifying people's emotions } \\
\text { such as the level of fear and } \\
\text { panic about COVID-19 }\end{array}$ & - \\
\hline 7 & $\begin{array}{l}\text { Extending a Chronological and } \\
\text { Geographical Analysis of Personal }\end{array}$ & $\begin{array}{l}\text { - Identifying the early signs of } \\
\text { an outbreak in an area by }\end{array}$ & - \\
\hline
\end{tabular}




\begin{tabular}{|c|c|c|c|}
\hline \multirow{2}{*}{ Row } & \multirow{2}{*}{ Title } & \multicolumn{2}{|c|}{ Consequence } \\
\hline & & Advantage & Disadvantage \\
\hline & $\begin{array}{l}\text { Reports of COVID-19 on Twitter to } \\
\text { England, UK(Golder et al., 2020) }\end{array}$ & $\begin{array}{l}\text { analyzing the data available on } \\
\text { Twitter }\end{array}$ & \\
\hline 8 & $\begin{array}{l}\text { Coronavirus, Ageism, and Twitter: } \\
\text { An Evaluation of Tweets about } \\
\text { Older Adults and COVID- } \\
\text { 19(Jimenez-Sotomayor et al., 2020) }\end{array}$ & $\begin{array}{l}\text { - Rapid sharing of the results of } \\
\text { scientific investigations } \\
\text { - Providing and receiving social } \\
\text { support, overcoming loneliness } \\
\text { (especially in the period of } \\
\text { social distancing), and } \\
\text { strengthening the sense of self- } \\
\text { efficacy using Twitter }\end{array}$ & $\begin{array}{l}\text { - Low quality and } \\
\text { reliability of published } \\
\text { health-related information } \\
\text { - Sharing offensive and } \\
\text { ridiculous information } \\
\text { towards middle-aged } \\
\text { people in the period of the } \\
\text { COVID-19 epidemic }\end{array}$ \\
\hline 9 & $\begin{array}{l}\text { Misinformation about spinal } \\
\text { manipulation and boosting } \\
\text { immunity: an analysis of Twitter } \\
\text { activity during the COVID-19 crisis } \\
\text { (Kawchuk et al., 2020) }\end{array}$ & - & $\begin{array}{l}\text { - Presenting false medical } \\
\text { information } \\
\text { - Deliberate and purposeful } \\
\text { presentation of false and } \\
\text { invalid information by } \\
\text { users }\end{array}$ \\
\hline 10 & $\begin{array}{l}\text { A Chronological and Geographical } \\
\text { Analysis of Personal Reports of } \\
\text { COVID-19 on Twitter (Klein et al., } \\
\text { 2020) }\end{array}$ & $\begin{array}{l}\text { - The use of personal tweets as a } \\
\text { signal for the prevalence of } \\
\text { COVID-19 in an area }\end{array}$ & - \\
\hline 11 & $\begin{array}{l}\text { Coronavirus Goes Viral: } \\
\text { Quantifying the COVID-19 } \\
\text { Misinformation Epidemic on Twitter } \\
\text { (Kouzy et al., 2020) }\end{array}$ & - & $\begin{array}{l}\text { - Presenting unreliable and } \\
\text { false information by some } \\
\text { Twitter accounts } \\
\text { - The rapid spread of false } \\
\text { information among users }\end{array}$ \\
\hline 12 & $\begin{array}{l}\text { Using Social Media for Rapid } \\
\text { Information Dissemination in a } \\
\text { Pandemic: \#PedsICU and } \\
\text { Coronavirus Disease } 2019 \\
\text { (Kudchadkar \& Carroll, 2020) }\end{array}$ & $\begin{array}{l}\text { - The sharing of information, } \\
\text { immediate access to the latest } \\
\text { information } \\
\text { - The use of Twitter as a virtual } \\
\text { library that is updated } \\
\text { automatically } \\
\text { - Availability to everyone } \\
\text { - The sharing of information by } \\
\text { health professionals and } \\
\text { physicians } \\
\text { - Immediate access to } \\
\text { educational information }\end{array}$ & \\
\hline 13 & $\begin{array}{l}\text { Machine Learning to Detect Self- } \\
\text { Reporting of Symptoms, Testing } \\
\text { Access, and Recovery Associated } \\
\text { With COVID-19 on Twitter: } \\
\text { Retrospective Big Data Infoveillance } \\
\text { Study (Mackey et al., 2020) }\end{array}$ & $\begin{array}{l}\text { - The use of Twitter to inform } \\
\text { about emerging topics such as } \\
\text { the prevalence of infectious } \\
\text { diseases } \\
\text { - The use of available } \\
\text { experiences in social media to } \\
\text { estimate the severity of the } \\
\text { disease among people }\end{array}$ & - \\
\hline 14 & $\begin{array}{l}\text { Application of Topic Modeling to } \\
\text { Tweets as the Foundation for Health } \\
\text { Disparity Research for COVID-19 } \\
\text { (Odlum et al., 2020) }\end{array}$ & & $\begin{array}{l}\text { - Deliberate sharing of } \\
\text { invalid information by } \\
\text { some people to guide their } \\
\text { plans }\end{array}$ \\
\hline
\end{tabular}




\begin{tabular}{|c|l|l|l|}
\hline \multirow{2}{*}{ Row } & \multicolumn{1}{|c|}{ Title } & \multicolumn{2}{c|}{ Consequence } \\
\cline { 3 - 4 } & & \multicolumn{1}{c|}{ Advantage } & \multicolumn{1}{c|}{ Disadvantage } \\
\hline 15 & $\begin{array}{l}\text { World leaders' usage of Twitter in } \\
\text { response to the COVID-19 } \\
\text { pandemic: a content analysis (Rufai } \\
\text { \& Bunce, 2020) }\end{array}$ & $\begin{array}{l}\text { - A powerful tool for political } \\
\text { leaders to communicate with } \\
\text { citizens and individuals } \\
\text { - The use of twitter as a source } \\
\text { of information for individuals } \\
\text { among the people towards } \\
\text { systems }\end{array}$ & \\
\hline 16 & $\begin{array}{l}\text { Retweeting COVID-19 disability } \\
\text { issues: Risks, support, and outrage } \\
\text { (Thelwall \& Levitt, 2020) }\end{array}$ & $\begin{array}{l}\text { - Informing about patients with } \\
\text { certain disabilities } \\
\text { - Changing the policies to pay } \\
\text { more attention to people with } \\
\text { disabilities }\end{array}$ & - \\
\hline 17 & $\begin{array}{l}\text { Conversations and Medical News } \\
\text { Frames on Twitter: } \\
\text { Infodemiological Study on COVID- } \\
\text { 19 in South Korea (Park et al., 2020) }\end{array}$ & & \multicolumn{1}{|c|}{-} \\
\hline
\end{tabular}

Table 3. Advantages and disadvantages of the use of Twitter in the period of the COVID-19 crisis.

\section{Discussion}

The present study provides a comprehensive overview of the opinions, experiences, and emotions shared by users on Twitter and the advantages and disadvantages of using this social network during the COVID-19 crisis. As can be interpreted from the results, the tweets related to the COVID-19 crisis increased sharply during the pandemic.

An extensive range of tweets has been shared by users and the general public, although politicians (Rufai \& Bunce, 2020; Yum, 2020), physicians, and health professionals (Kudchadkar \& Carroll, 2020; Wahbeh et al., 2020) have also utilized this platform to share news and provide information to people. Regular users on Twitter share most of their opinions, experiences, and feelings about the crisis. The politicians' activities have been mostly to boost morale, raise awareness, and report on government policies to cope with the COVID-19 crisis. Physicians and health professionals have also attempted to inform, advise, and educate people on health measures.

Previous studies on the use of Twitter in past crises also revealed that the use of Twitter increased significantly during previous crises. Moreover, Twitter was used primarily as a tool to raise awareness of the current situation and identify measures to reduce the risks of crises, and with the rapid change of the current situation, this tool was an excellent solution for fast communications (Brandt et al., 2019). Due to the increasing use of social media, twitter makes a major contribution to make people aware of emergencies, prevent injury in times of crisis, and assist in compensating for injuries and recovering (Houston et al., 2015).

The increasing interest of users in sharing comments and information on Twitter has led to a growth in false information at the onset of the COVID-19 crisis, which is one of the main problems with social media and Twitter during the crisis. False information (Especially in the form of the word "Corona") rapidly spreads among Twitter users. Also, accounts with fewer 
followers provided less false information, and the most reliable information was presented by accounts related to health care services, which had the lowest amount of false information (Kouzy et al., 2020). Also, different people for different reasons and to advance their goals, make their followers distrustful of the government and official news about COVID-19, the method of treatment, and the mortality rate by providing false information that can lead to feelings of fear and ignoring the prevention methods offered by the government and reputable organizations (Odlum et al., 2020). Moreover, many tweets refer to treatment methods for COVID-19 for which there is no scientific evidence (Kawchuk et al., 2020).

In general, rumors and false information on social media can spread quickly to a wide range of users in different places, directly affecting individuals' behaviors, decisions, and actions (Tang et al., 2015). In this regard, Sunstein (2014) claims that people believe and reshare the rumors that are most shared. Lee and Oh (2017) also confirm this claim for tweets and retweets. Hence, rumors and misinformation must be managed before they become extensively shared and popular.

The use of Twitter during the COVID-19 crisis has many advantages, including immediate communication between people, organizations, and governments, and the rapidity of providing information to people (Abd-Alrazaq et al., 2020; Aguilar-Gallegos et al., 2020; Chen et al., 2020b; Jimenez-Sotomayor et al., 2020; Kudchadkar \& Carroll, 2020; Mackey et al., 2020; Thelwall \& Levitt, 2020). Moreover, the data available on Twitter is used as a source for identifying geographical areas at risk and the outbreak of COVID-19 (Bisanzio et al., 2020; Klein et al., 2020; Mackey et al., 2020; Rufai \& Bunce, 2020). Therefore, this data is increasingly useful for enhancing situational awareness and assisting in disaster management (Wang et al., 2015; Yang et al., 2016).

As previous studies have shown, social media provides a platform for commenting on posts that help develop interactions between affected populations and related organizations. Therefore, these organizations can gain information for identifying places and population affected, and for policy development during a crisis (Tang et al., 2015; Scott and Errett, 2018; Tim et al., 2017).

\section{Conclusion}

The COVID-19 pandemic has affected many health care systems and countries and taken the lives of many people. Due to many people's presence and activity on social media, especially Twitter, it is necessary to pay attention to health care activities and the published information.

Twitter can be used as a tool for quickly providing information in times of crisis. Over the past decade, Twitter has proven to be a valuable resource in the event of a disaster for many critical communications (Banda et al., 2020). This tool can be employed as a communication strategy to share information and emergency warnings and start a two-way conversation between respondents and people affected by the crisis. Analyzing tweets posted on Twitter can help understand the feelings of people affected by natural disasters, their needs, and the damage caused by the crisis. The data on Twitter can also be used to identify different areas involved in the crisis.

The investigations indicate that the content and tweets posted on Twitter were affected by the crisis at the time of the COVID-19 outbreak, and different people shared their personal opinions, feelings, and experiences of encountering COVID-19 on this social media. Health professionals and politicians also utilized this platform as a tool for providing information and education about COVID-19. 
While the use of Twitter has many advantages, such as the rapidity of providing information to people, the risk of spreading rumors and using invalid information without scientific citation has also raised concerns among people, governments, and health organizations.

However, at such times, e-health literacy skills can help prevent the spread of the disease. "Electronic health literacy" is the skill and ability to search, find, understand, and assess health information from electronic sources and employ it to diagnose or eliminate a specific health disorder (Norman, 2011). Therefore, people with higher e-health literacy skills have a higher ability to identify high-quality health information.

Accordingly, individuals and users should evaluate information accuracy more carefully and pay attention to its quality and validity before employing or sharing it. The role of health-related organizations in informing and educating people on promoting e-health literacy is also essential.

Given the abovementioned issues, social media, especially Twitter, can be considered as a twoway tool. On the one hand, it can be used as a powerful weapon to distribute knowledge and information among people directly; and, on the other hand, if not correctly used, it can be detrimental to the health system's efforts to deal with the crisis. Therefore, the need for a more active and stronger presence of public health organizations on social media is felt more extensively during the COVID-19 crisis. These efforts should be such that the activities dealing with the public health crisis should be simultaneously considered in the real world and on social media.

Therefore, health-related organizations should create official accounts on Twitter and provide valid health-related information to their followers. These organizations should also monitor the shared content on social media during the crisis to stop the spread of false news and rumors and raise public awareness as soon as possible.

\section{ORCID}

Mahsa Dalili Shoaei (D) http://orcid.org/0000-0002-7845-5991

Meisam Dastani (D) http://orcid.org/0000-0002-5631-539X

\section{References}

Abbas, M. A., Eliyana, A., Ekowati, D., Saud, M. M., Raza, M. A., \& Wardani, M. R. (2020). Data set on coping strategies in the digital age: The role of psychological well-being and social capital among university students in Java Timor, Surabaya, Indonesia. Data in Brief, 30, 105583. https://doi.org/10.1016/i.dib.2020.105583

Abd-Alrazaq, A., Alhuwail, D., Househ, M., Hamdi, M., \& Shah, Z. (2020). Top Concerns of Tweeters During the COVID-19 Pandemic: Infoveillance Study. Journal of Medical Internet Research, 22(4), e19016. https://doi.org/10.2196/19016

Aguilar-Gallegos, N., Romero-García, L. E., Martínez-González, E. G., García-Sánchez, E. I., \& AguilarÁvila, J. (2020). Dataset on dynamics of Coronavirus on Twitter. Data in Brief, 30, 105684. https://doi.org/10.1016/j.dib.2020.105684

Allcott, H., Gentzkow, M., \& Yu, C. (2019). Trends in the diffusion of misinformation on social media. Research \& Politics, 6(2), 1-8. https://doi.org/10.1177/2053168019848554

Amani, F., Aghaie, B., Zeynizadeh, S., Tabrizian, S., Aslanian, R., \& Jafarizadeh, R. (2020). Using social network rates among Ardabil city women over 25 years old. Journal of Human Sport and Exercise, 15(S429-S436). https://doi.org/10.14198/jhse.2020.15.Proc2.33

Auter, P. J., Douai, A., Makady, H., \& West, C. (2016). Circulating health rumors in the 'Arab World': a 12-month content analysis of news stories and reader commentary about Middle East Respiratory Syndrome from two Middle Eastern news outlets. International Communication Gazette, 78(5), 411-431.

https://doi.org/10.1177/1748048516640202 
Banda, J. M., Tekumalla, R., Wang, G., Yu, J., Liu, T., Ding, Y., \& Chowell, G. (2020). A large-scale COVID-19 Twitter chatter dataset for open scientific research - An international collaboration. arXiv preprint arXiv:2004.03688. https://arxiv.org/abs/2004.03688

Brandt, H. M., Turner-McGrievy, G., Friedman, D. B., Gentile, D., Schrock, C., Thomas, T., \& West, D. (2019). Examining the role of Twitter in response and recovery during and after historic flooding in South Carolina. Journal of Public Health Management and Practice, 25(5), E6-E12. https://doi.org/10.1097/PHH.0000000000000841

Barros, J. M., Duggan, J., \& Rebholz-Schuhmann, D. (2020). The application of internet-based sources for public health surveillance (infoveillance): Systematic review. Journal of Medical Internet Research, 22(3), e13680. https://doi.org/10.2196/13680

Bisanzio, D., Kraemer, M. U., Bogoch, I. I., Brewer, T., Brownstein, J. S., \& Reithinger, R. (2020). Use of Twitter social media activity as a proxy for human mobility to predict the spatiotemporal spread of COVID19 at global scale. Geospatial Health, 15(1), 19-24. https://doi.org/10.4081/gh.2020.882

Boyd, D. M., \& Ellison, N. B. (2007). Social network sites: Definition, history, and scholarship. Journal of Computer-Mediated Communication, 13(1), 210-230. https://doi.org/10.1111/.1.1083-6101.2007.00393.x

Budhwani, H., \& Sun, R. (2020). Creating COVID-19 Stigma by Referencing the Novel Coronavirus as the "Chinese virus" on Twitter: Quantitative Analysis of Social Media Data. Journal of Medical Internet Research, 22(5), e19301. https://doi.org/10.2196/19301

Chae, J., Thom, D., Jang, Y., Kim, S., Ertl, T., \& Ebert, D. S. (2014). Public behavior response analysis in disaster events utilizing visual analytics of microblog data. Computers \& Graphics, 38, 51-60. https://doi.org/10.1016/j.cag.2013.10.008

Chen, E., Lerman, K., \& Ferrara, E. (2020a). Covid-19: The first public coronavirus twitter dataset. arXiv preprint arXiv:2003.07372. https://arxiv.org/abs/2003.07372

Chen, E., Lerman, K., \& Ferrara, E. (2020b). Tracking Social Media Discourse About the COVID-19 Pandemic: Development of a Public Coronavirus Twitter Data Set. JMIR Public Health Surveill, 6(2), e19273. https://doi.org/10.2196/19273

Dastani, M., Keramati, J., Poorfatemi, A., \& Ekrami, A. (2015). The reasons and motives of virtual social networks among students of Gonabad University of Medical Sciences. Caspian Journal of Scientometrics, 2(2), 24-27. https://doi.org/10.22088/acadpub.BUMS.2.2.24

Dastani, M., Keramati, J., Poorfatemi, A., \& Ekrami, A. (2016). The role of Social Networks on Academic Achievement of Gonabad University of Medical Science' students. Journal of Medical Education and Development, 11(2), 153-160.

Dastani, M., Mohammadpour, A., \& Bagheri, J. (2019). The Opportunities and Damages of Virtual Social Networks from Students' Perspectives; the Experience of Iranian Users. Library Philosophy and Practice, 2956. https://digitalcommons.unl.edu/libphilprac/2956/

Dastani, M., \& Ramezani, A. (2017). Role of Membership in Scientific and Specialized Groups of Virtual Social Networks in Increasing Knowledge, Professional Skills and E-Learning: A Case Study. International Research: Journal of Library and Information Science, 7(4), 595-602.

Elwyn, G., Scholl, I., Tietbohl, C., Mann, M., Edwards, A. G., Clay, C., Légaré, F., Weijden, T. van der, Lewis, C. L., Wexler, R. M., \& Frosch, D. L. (2013). "Many miles to go ...": a systematic review of the implementation of patient decision support interventions into routine clinical practice. BMC Medical Informatics and Decision Making, 13(S2). https://doi.org/10.1186/1472-6947-13-s2-s14

Goff, D. A., Kullar, R., Laxminarayan, R., Mendelson, M., Nathwani, D., \& Osterholm, M. (2019). Twitter to engage, educate, and advocate for global antibiotic stewardship and antimicrobial resistance. The Lancet Infectious Diseases, 19(3), 229-231. https://doi.org/10.1016/S1473-3099(19)30058-1

Golder, S., Klein, A., Magge, A., O'Connor, K., Cai, H., \& Weissenbacher, D. (2020). Extending A Chronological and Geographical Analysis of Personal Reports of COVID-19 on Twitter to England, UK. medRxiv. https://doi.org/10.1101/2020.05.05.20083436

Goodchild, M. F., \& Glennon, J. A. (2010). Crowdsourcing geographic information for disaster response: a research frontier. International Journal of Digital Earth, 3(3), 231-241. https://doi.org/10.1080/17538941003759255

Gui, X., Kou, Y., Pine, K. H., \& Chen, Y. (2017). Managing uncertainty: using social media for risk assessment during a public health crisis. In Proceedings of the $2017 \mathrm{CHI}$ Conference on Human Factors in Computing Systems (pp. 4520-4533). https://doi.org/10.1145/3025453.3025891

Houston, J. B., Hawthorne, J., Perreault, M. F., Park, E. H., Goldstein Hode, M., Halliwell, M. R., Turner McGowen, S. E., Davis, R., Vaid, S., McElderry, J. A., \& Griffith, S. A. (2014). Social media and 
disasters: a functional framework for social media use in disaster planning, response, and research. Disasters, 39(1), 1-22. https://doi.org/10.1111/disa.12092

Hou, C., Chen, J., Zhou, Y., Hua, L., Yuan, J., He, S., Guo, Y., Zhang, S., Jia, Q., Zhao, C., Zhang, J., Xu, G., \& Jia, E. (2020). The effectiveness of quarantine of Wuhan city against the Corona Virus Disease 2019 (COVID-19): A well-mixed SEIR model analysis. Journal of Medical Virology, 92(7), 841-848. https://doi.org/10.1002/jmv.25827

Jimenez-Sotomayor, M. R., Gomez-Moreno, C., \& Soto-Perez-de-Celis, E. (2020). Coronavirus, Ageism, and Twitter: An Evaluation of Tweets about Older Adults and COVID-19. Journal of the American Geriatrics Society, 68(8), 1661-1665. https://doi.org/10.1111/jgs.16508

Kawchuk, G., Hartvigsen, J., Harsted, S., Nim, C. G., \& Nyirö, L. (2020). Misinformation about spinal manipulation and boosting immunity: an analysis of Twitter activity during the COVID-19 crisis. Chiropractic \& Manual Therapies, 28(1), 34. https://doi.org/10.1186/s12998-020-00319-4

Klein, A., Magge, A., O'Connor, K., Cai, H., Weissenbacher, D., \& Gonzalez-Hernandez, G. (2020). A Chronological and Geographical Analysis of Personal Reports of COVID-19 on Twitter. medRxiv. https://doi.org/10.1101/2020.04.19.20069948

Kouzy, R., Abi Jaoude, J., Kraitem, A., El Alam, M. B., Karam, B., Adib, E., Zarka, J., Traboulsi, C., Akl, E., \& Baddour, K. (2020). Coronavirus Goes Viral: Quantifying the COVID-19 Misinformation Epidemic on Twitter. Cureus, 12(3), e7255. https://doi.org/10.7759/cureus.7255

Kostkova, P., De Quincey, E., \& Jawaheer, G. (2010). The potential of social networks for early warning nad outbreak detection systems: the swine flu Twitter study. International Journal of Infectious Diseases, 14 e384-e385. https://doi.org/10.1016/j.ijid.2010.02.475

Kudchadkar, S. R., \& Carroll, C. L. (2020). Using Social Media for Rapid Information Dissemination in a Pandemic. Pediatric Critical Care Medicine, Publish Ahead of Print. https://doi.org/10.1097/pcc.0000000000002474

Lee, H., \& Oh, H. J. (2017). Normative mechanism of rumor dissemination on Twitter. Cyberpsychology, Behavior, and Social Networking, 20(3), 164-171. https://doi.org/10.1089/cyber.2016.0447

Kullar, R., Goff, D. A., Gauthier, T. P., \& Smith, T. C. (2020). To Tweet or Not to Tweet-a Review of the Viral Power of Twitter for Infectious Diseases. Current Infectious Disease Reports, 22, Article 14. https://dx.doi.org/10.1007/s11908-020-00723-0

Leelawat, N., Tang, J., Saengtabtim, K., \& Laosunthara, A. (2020). Trends of Tweets on the Coronavirus Disease-2019 (COVID-19) Pandemic. Journal of Disaster Research, 4(15), 530-533.

Li, Q., Guan, X., Wu, P., Wang, X., Zhou, L., Tong, Y., Ren, R., Leung, K. S. M., Lau, E. H. Y., Wong, J. Y., Xing, X., Xiang, N., Wu, Y., Li, C., Chen, Q., Li, D., Liu, T., Zhao, J., Li, M., ... Feng, Z. (2020). Early Transmission Dynamics in Wuhan, China, of Novel Coronavirus-Infected Pneumonia. The New England Journal of Medicine, 382(13). https://doi.org/10.1056/NEJMoa2001316

Liu, Q., Gao, Y., \& Chen, Y. (2014). Study on disaster information management system compatible with VGI and crowdsourcing. In The 2014 IEEE Workshop on Advanced Research and Technology in Industry Applications (WARTIA). IEEE. https://doi.org/10.1109/WARTIA.2014.6976296

Lwin, M. O., Lu, J., Sheldenkar, A., Schulz, P. J., Shin, W., Gupta, R., \& Yang, Y. (2020). Global sentiments surrounding the COVID-19 pandemic on Twitter: analysis of Twitter trends. JMIR Public Health Surveill, 6(2), e19447. https://doi.org/10.2196/19447

Mackey, T., Purushothaman, V., Li, J., Shah, N., Nali, M., Bardier, C., ... Cuomo, R. (2020). Machine Learning to Detect Self-Reporting of Symptoms, Testing access, and Recovery Associated With COVID-19 on Twitter: Retrospective Big Data Infoveillance Study. JMIR Public Health Surveill, 6(2), e19509. https://doi.org/10.2196/19509

Madge, C., Meek, J., Wellens, J., \& Hooley, T. (2009). Facebook, social integration and informal learning at university:'It is more for socialising and talking to friends about work than for actually doing work'. Learning, media and technology, 34(2), 141-155. https://doi.org/10.1080/17439880902923606

Norman, C. (2011). eHealth literacy 2.0: problems and opportunities with an evolving concept. Journal of Medical Internet Research, 13(4), e125. https://doi.org/10.2196/jmir.2035

Odlum, M., Cho, H., Broadwell, P., Davis, N., Patrao, M., Schauer, D., ... Yoon, S. (2020). Application of Topic Modeling to Tweets as the Foundation for Health Disparity Research for COVID-19. In The Importance of Health Informatics in Public Health during a Pandemic, (pp. 24-27). https://doi.org/10.3233/SHTI200484

Odlum, M., \& Yoon, S. (2015). What can we learn about the Ebola outbreak from tweets?. American journal of infection control, 43(6), 563-571. https://dx.doi.org/10.1016/j.ajic.2015.02.023 
Panuganti, B. A., Jafari, A., MacDonald, B., \& DeConde, A. S. (2020). Predicting COVID-19 Incidence Using Anosmia and Other COVID-19 Symptomatology: Preliminary Analysis Using Google and Twitter. Otolaryngology-Head and Neck Surgery, 163(3), 491-497. https://doi.org/10.1177/0194599820932128

Paré, G., \& Kitsiou, S. (2017). Methods for literature reviews. In Handbook of eHealth Evaluation: An Evidencebased Approach. University of Victoria.

Park, H. W., Park, S., \& Chong, M. (2020). Conversations and Medical News Frames on Twitter: Infodemiological Study on COVID-19 in South Korea. Journal of Medical Internet Research, 22(5), e18897. https://doi.org/10.2196/18897

Pempek, T. A., Yermolayeva, Y. A., \& Calvert, S. L. (2009). College students' social networking experiences on Facebook. Journal of Applied Developmental Psychology, 30(3), 227-238. https://doi.org/10.1016/j.appdev.2008.12.010

PRISMA. (2015). PRISMA Checklist. http://prisma-statement.org/PRISMAStatement/Checklist.aspx

Rizo, C. A., Lupea, D., Baybourdy, H., Anderson, M., Closson, T., \& Jadad, A. R. (2005). What Internet services would patients like from hospitals during an epidemic? Lessons from the SARS outbreak in Toronto. Journal of Medical Internet Research, 7(4), e46. https://doi.org/10.2196/jmir.7.4.e46

Rufai, S. R., \& Bunce, C. (2020). World leaders' usage of Twitter in response to the COVID-19 pandemic: a content analysis. Journal of Public Health, 42(3), 510-516. https://doi.org/10.1093/pubmed/fdaa049

Sarker, A., Lakamana, S., Hogg-Bremer, W., Xie, A., Al-Garadi, M. A., \& Yang, Y. C. (2020). Self-reported COVID-19 symptoms on Twitter: an analysis and a research resource. Journal of the American Medical Informatics Association, 27(8), 1310-1315. https://doi.org/10.1093/jamia/ocaa116

Scott, K. K., \& Errett, N. A. (2018). Content, Accessibility, and Dissemination of Disaster Information via Social Media During the 2016 Louisiana Floods. Journal of Public Health Management and Practice, 24(4), 370 379. https://doi.org/10.1097/phh.0000000000000708

Scheufele, D. A., \& Krause, N. M. (2019). Science audiences, misinformation, and fake news. Proceedings of the National Academy of Sciences, 116(16), 7662-7669. https://doi.org/10.1073/pnas.1805871115

Su, Y., Xue, J., Liu, X., Wu, P., Chen, J., Chen, C., ... Zhu, T. (2020). Examining the Impact of COVID-19 Lockdown in Wuhan and Lombardy: A Psycholinguistic Analysis on Weibo and Twitter. International journal of environmental research and public health, 17(12), Article 4552. https://doi.org/10.3390/ijerph17124552

Sunstein, C. (2014). On Rumors: How Falsehoods Spread, Why We Believe Them, and What Can Be Done. Princeton University Press.

Tang, Z., Zhang, L., Xu, F., \& Vo, H. (2015). Examining the role of social media in California's drought risk management in 2014. Natural Hazards, 79(1), 171-193. https://doi.org/10.1007/s11069-015-1835-2

Thelwall, M., \& Levitt, J. M. (2020). Retweeting Covid-19 disability issues: Risks, support and outrage. El profesional de la información, 29(2), e290216. https://doi.org/10.3145/epi.2020.mar.16

Tim, Y., Pan, S. L., Ractham, P., \& Kaewkitipong, L. (2017). Digitally enabled disaster response: the emergence of social media as boundary objects in a flooding disaster. Information Systems Journal, 27(2), 197-232. https://doi.org/10.1111/isj.12114

Vieweg, S. (2010). Microblogged contributions to the emergency arena: Discovery, interpretation and implications. In Proceedings of the Computer Supported Collaborative Work 2010 (pp. 515-516). ACM.

Vosoughi, S., Roy, D., \& Aral, S. (2018). The spread of true and false news online. Science, 359(6380), 11461151. https://doi.org/10.1126/science.aap9559

Wahbeh, A., Nasralah, T., Al-Ramahi, M., \& El-Gayar, O. (2020). Mining Physicians' Opinions on Social Media to Obtain Insights Into COVID-19: Mixed Methods Analysis. JMIR Public Health Surveill, 6(2), e19276. https://doi.org/10.2196/19276

Walther, J., \& Parks, M. (2002). Cues Filtered Out, Cues Filtered in: Computer Mediated Communication and Relationships. In Handbook of interpersonal communication (pp. 529-563). Sage.

Wang, Y., Wang, T., Ye, X., Zhu, J., \& Lee, J. (2015). Using social media for emergency response and urban sustainability: A case study of the 2012 Beijing rainstorm. Sustainability, 8(1), 1-17. https://doi.org/10.3390/su8010025

Wang, W., Ma, Y., Wu, T., Dai, Y., Chen, X., \& Braunstein, L. A. (2019). Containing misinformation spreading in temporal social networks. Chaos: An Interdisciplinary Journal of Nonlinear Science, 29(12), Article 123131. https://doi.org/10.1063/1.5114853 
Yang, X., Ye, X., \& Sui, D. Z. (2016). We know where you are: In space and place-enriching the geographical context through social media. International Journal of Applied Geospatial Research, 7(2), 61-75. https://doi.org/10.4018/lJAGR.2016040105

Yum, S. (2020). Social Network Analysis for Coronavirus (COVID-19) in the United States. Social Science Quarterly, 101(4), 1642-1647. https://doi.org/10.1111/ssqu.12808

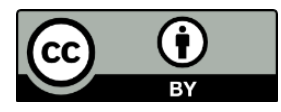

Copyright (C) 2020 by the author(s). Licensee Prague University of Economics and Business Czech Republic. This article is an open access article distributed under the terms and conditions of the Creative Commons Attribution License (CC BY), which permits use, distribution and reproduction in any medium, provided the original publication is properly cited, see http://creativecommons.org/licenses/by/4.0/. No use, distribution or reproduction is permitted which does not comply with these terms.

The article has been peer-reviewed.

Editorial record: First submission received on 30 August 2020. Revisions received on 19 September 2020 and 26 September 2020. Accepted for publication on 29 September 2020. The editor in charge coordinating the peer-review of this manuscript and approving it for publication was Zdenek Smutny (D). 